Historic, Archive Document

Do not assume content reflects current scientific knowledge, policies, or practices. 

$W W^{\mathrm{E}}$ wish to call your attention to our B \& B Evergreens listed herein. They include some very fine plants. After years of experience we have learned to dig and burlap them right. They have been well grown and you will be well pleased with them.

Because of a large supply we have reduced the price on the following items. Norway Spruce, Scotch, Austrian, Uncinata and Mugho pine, Seedlings. Hydrangea P. G. Spirea billardi, Sugar Maple and American Elm.

We invite your correspondence and will be glad to make special quotations on large quantities.

Express, Freight and Telegraph"Offices, Salem, Ohio

\section{Trade Price List - January 24, 1930}

\section{TERMS}

Three hundred at 1000 rates, 25 at hundred rates. Shipments travel at buyers risk. We disclaim all responsibility after delivery to forwarding Company.

C. O. D. orders must be accompanied by one-fourth cash. Orders to be slipped by parcel post must be accompanied by sufficient funds to cover postage. Any balance received and not used for this purpose will be refunded immediately when shipment is made.

Prices are net, packing additional at cost.

We have Permits and special Tags for shipping into almost every state. We will fumigate where state laws require it.

This price list cancels all previous lists.

Ask for Sample Page of book, "Art of Propagation." References: First National Bank, Salem Ohio and Commercial Agencies

\section{J. JENKINS \& SON MEMBERS

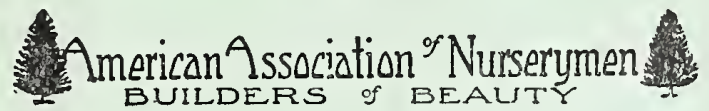

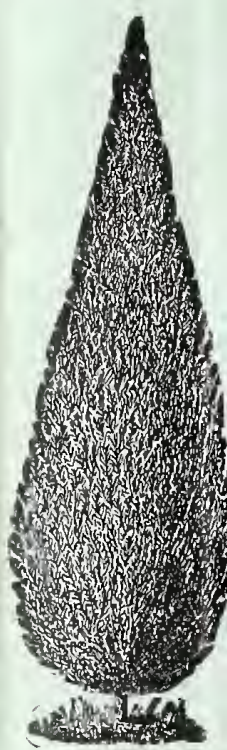

J. JENKINS \& SON COLUMBIANA CO. WINONA, OHIO

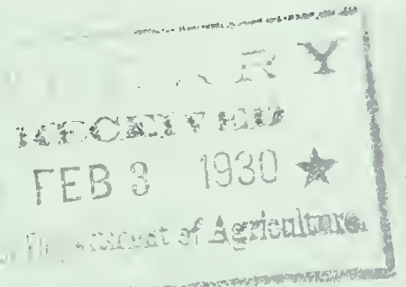

Sec, 435 1-2 P. L. \& R

U. S. POSTAGE PAID WINONA, OHIO

Permit No. 1

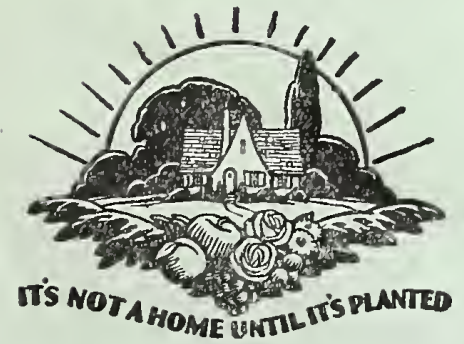




\section{EVERGREENS}

\section{BIES BALSAMEA (Balsam fir) Each}

\section{Seedlings}

1 to 3 in

Transplants

4 to 6 in.

$1.50 \quad 10.00$ 6 to $8 \mathrm{in}$.

BIES CONCOLOR (Concolor fir)

Transplants B\&B 10 to 12 in. 1.00 , 12 to 18 in. 1.50

$$
\text { " } \quad 18 \text { to } 24 \text { in. } 2.00
$$

ABIFS FRASERI (Fraser's fir)

$\begin{array}{llll}\text { Seedlings } & 2 \text { to } 4 \text { in. } & 4.00 & 30.00\end{array}$

ABIES NORDMANIANA (Nordman Fir)

Seedlings 2 to $4 \mathrm{in}$.

BUXUS (Sempervirens Boxwood)

CHAMALCYPARIS LAWSONIANA, (Lawson Cypres

Seedlings

4 to 6 in

6 to 8 in.

Transplants B.\&B. 12 to $18 \mathrm{in}$.

$\begin{array}{rrrrr}" & \text { " } & 18 \text { to } 24 \text { in. } & 1.00 & 40.00 \\ " & \text { " } & 3 \mathrm{ft} . & 2.00 & \\ " & & 4 \mathrm{ft} . & 3.00 & \end{array}$

CHAMAECYPARIS OBTUSA (Hinoki cypress)

Seedlings

$$
2 \text { to } 4 \text { in. } 3.00
$$

Transplants B\&B 18 to 24 in. 1.25

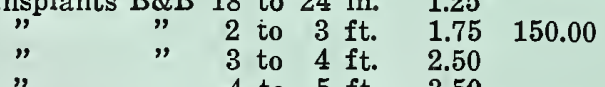

Obtusa transplanted three times from seed Considerable variation. All nice stock.

CHAMAECYPARIS PISIFERA (Sawara cypress)

$$
\begin{aligned}
& \text { Transplants } \quad 6 \text { to } 10 \text { ir. } \quad .25 \quad 20.00 \\
& \text { " B\&B } 12 \text { to } 18 \text { in, } 1.00 \quad 80.00 \\
& \text { " } \quad 18 \text { to } 24 \mathrm{in}_{1} \quad 1.50 \quad 100.00 \\
& 2 \text { to } 3 \mathrm{ft} \\
& 3 \text { to } 4 \text { ft. } 3.00 \quad 250.00
\end{aligned}
$$

CHAMAECYPARIS PISIFERA AUREA (Golden S. cypress)

$$
\begin{array}{rrrrr}
\text { Transplants } & 6 \text { to } 10 \text { in. } & & 25.00 \\
\text { "B\&B } & 12 \text { to } 18 \text { in. } & 1.25 & 120.00 \\
" ~ & 18 \text { to } 24 \text { in. } & 1.75 & 160.00 \\
\text { " } & 2 \text { to } 3 \mathrm{ft} . & 2.50 & 225.00
\end{array}
$$

3 to $4 \mathrm{ft}$. 3.25

CHAMAECYPARIS PISIFERA, FLLIFERA (Thread cypress)

Transplants

6 to $10 \mathrm{in}$.

20.00

" B\&B $\quad 12$ to 18 in. 1.00

24 to 36 in. 2.00

CHAMAECYPARIS PISIFERA PLUMOSA (Plume cypress)

Transplants

$\begin{array}{lrrrr}\text { " B\&B } & 12 \text { to } 18 \text { in. } & & 15.00 \\ " \text { " } & 18 \text { to } 24 \text { in. } & 1.00 & 60.00 \\ " & 2 \text { to } 3 \mathrm{ft} . & 1.75 & 150.00\end{array}$

ChaMaECYPARIS PIS PLUMOSA AUREA (Golden Plume)

Transplants 4 to 6 in. 20.00 "B\&B 12 to 18 in. $1.00 \quad 80.00$ 18 to 24 in. 1.25100 .00

Transplants B\&B 2 to 3 f.t 2.001

CHAMAECYPARIS PIS. SQUARROSA

Transplants B\&B 18 to 24 in. 1.50

" " 2 to $3 \mathrm{ft} \quad 2.25$

CRYPTOMERIA JAPONICA

Seedlings 2 to 4 in.

JUNIPERUS HIBERNICA (Irish juniper)

Transplants B\&B 12 to 18 in $.75 \quad 50.00$ $\begin{array}{llcrrr}", & 18 \text { to } 24 \text { in } & 1.00 & 75.00 \\ ", & 2 \text { to } 3 \mathrm{ft} . & 1.50 & 125.00\end{array}$ " $\quad 3$ to $4 \mathrm{ft}$. $2.50 \quad 225.00$ " $\quad 4$ ft. \& up 3.50

JUNIPERUS PFITZERIANA (Pfitzer's juniper)

$\begin{array}{ccccc}" \text { B\&B } & 12 \text { to } 18 \text { in. } & 1.25 & 100.00 \\ \text { " } & 18 \text { to } 24 \text { in. } & 2.00 & 175.00 \\ " & 24 \text { to } 30 \text { in. } & 3.00 & 250.00\end{array}$

24 to $30 \mathrm{in.} \quad 3.00 \quad 250.00$

Pfitzers measured across.

JUNIPERUS SABINA (Savin Juniper)
Transplants
$"$ B\&B
4 to 6 in.
10 to $12 \mathrm{in}$
20.00
$" 12$ to 18 in.

JUNIPERUS SINENSIS VARIEGATA

Transplants 4 to 6 in.

$\begin{array}{lll}" \text { B\&B } & 10 \text { to } 12 \text { in. } & 1.00 \\ " \text { B\&B } & 12 \text { to } 18 \text { in. } & 1.75\end{array}$

12 to 18 in. 1.75
18 to 24 in. 2.50 
JUNIPERUS STRICTA (Greek janiper) Each 100

Transplants B\&B 10 to 12 in.

" B. \& , B. 12 to 18 in. 1.00

JUNIPERUS SUECICA (Swedish jmiper)

Transplants B\&B 10 to 12 in. 1.00 $"$ " $\quad 12$ to 18 in. 1.25

JUNIPERUS VIRGINIANA (Red cedar?

Seedlings $\quad 2$ to 4 in.

$4.50 \quad 35.00$

$6.00 \quad 50.00$

LARIX EUROPEA (European Larch)

Seedlings

$\begin{aligned} 2 \text { to } 4 \text { in. } & 1 . \\ 4 \text { to } 6 \text { in. } & 1 . \\ 6 \text { to } 12 \text { in. } & 2 . \\ 12 \text { to } 18 \text { in. } & 3.50 \\ 18 \text { to } 24 \text { in. } & 4.00\end{aligned}$

$\begin{array}{rr}1.00 & 7.00\end{array}$

$1.50 \quad 10.00$

$2.00 \quad 15.00$

$3.50 \quad 25.00$

$4.00 \quad 30.00$

$\begin{array}{lrl}" & 18 \text { to } 24 \mathrm{in} . & 4.00 \\ & 2 \text { to } 3 \mathrm{ft} . & 5.00\end{array}$

LARIX LEPTOLIS (Japanese Larch)

Seedlings

2 to 4 in $\quad 1.50$

10.00

$2.00 \quad 15.00$

6 to $12 \mathrm{in}$. $\quad 2.50 \quad 20.00$

$\begin{array}{llll}12 & \text { to } 18 \mathrm{in.} & 4.00 & 35.00 \\ " & 18 \text { to } 24 \mathrm{in.} & 4.50 & 40.00\end{array}$

$"$\begin{tabular}{rrr}
3 to $5 \mathrm{ft}$ & 7.00 \\
\hline OTHOE CATESBAEI (Drooping andromeda)
\end{tabular}

EUCOTHOE CATESBAEI (Drooping andromeda)
Transplants 6 to 12 in. $.40 \quad 35.00$ 12 to 18 in. $\quad .60 \quad 50.00$

PICEA CANADENSIS (ALBA) (White Spruce)

Seedlings

"'

2 to 4 in.

$1.00 \quad 6.00$

4 to 6 in. $\quad 1.50 \quad 10.00$

6 to $8 \mathrm{in.} \quad 2.50 \quad 18.00$

$\begin{array}{rrrr}8 \text { to } 10 \mathrm{in.} & 3.00 & 25.00 \\ & 10 \text { to } 12 \mathrm{in.} & 4.00 & 35.00\end{array}$

" 12 to 18 in.

Transplants B\&B 12 to 18 in. .75

5.00

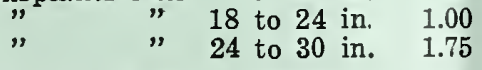

PICEA CANADENSIS ALBERTIANA (Blk. Hill's spruce)
Seedlings 2 yrs 2 to 3 in.
Transplants B\&B 12 to $18 \mathrm{in.} 1.00$
18 to 24 in. 1.50

$4.00 \quad 30.00$

PICEA ENGLEMANI (Engleman spruce)

$\begin{array}{ccccc}\text { Seedlings } & 2 \text { to } 4 \text { in. } & 2.00 & 15.00 \\ " & 4 \text { to } 6 \text { in. } & 3.00 & 25.00\end{array}$

PICEA EXCELSA (Norway spruce) 4 to 6 in.

" 6 to 8 in.

8 to $10 \mathrm{in.}$

10 to $12 \mathrm{in.}$

" $\quad 12$ to 18 in.

$\begin{array}{llll}" 6 & \text { to } 8 \mathrm{in.} & 4.00 & 30.00 \\ " & 8 \text { to } 10 \mathrm{in.} & 4.50 & 35.00\end{array}$

" 10 to $12 \mathrm{in.} \quad 5.00 \quad 45.00$

" B\&B $\quad 12$ to 18 in. $\quad .50 \quad 45.00$

18 to 24 in, $\quad .60 \quad 55.00$

2 to $3 \mathrm{ft} . \quad 80 \quad 75.00$

3 to $4 \mathrm{ft.} \quad 1.25 \quad 110.00$

4 to $5 \mathrm{ft.} \quad 2.00 \quad 175.00$

,"

5 to $6 \mathrm{ft}$. $\quad 3.00 \quad 275.00$

We can supply Norway Spruce in car lots.

PICEA POLITA (Tigertail spruce)

Seedlings 2 to 4 in.

15.00

PICEA PUNGENS (Colorado spruce. S. from blue tr. only) Seedlings 2 to 4 in. $2.50 \quad 20.00$

Med. blue tp B\&B 12 to 18 in. 2.50

Med. blue tp B\&B 18 to 24 in. 3.00

Med. blue tp B\&B 24 to 30 in. $\quad 5.00$

Green at half above prices

PINUS BANKSLANA (Jack pine)

Seedlings

6 to 12 in.

12 to $18 \mathrm{in}$.

18 to 24 in.

24 to 30 in.

$4.00 \quad 30.00$

PINUS DENSIFLORA (Japanese red pine)

Seedlings

4 to 6 in.

6 to 8 in.

8 to 10 in.

10 to 15 in.

$2.00 \quad 15.00$

$3.00 \quad 25.00$

$4.00 \quad 35.00$

5.00

$1.50 \quad 10.00$

$2.00 \quad 15.00$

$2.50 \quad 20.00$

$3.50 \quad 30.00$

PINUS EXCELSA (Bhotan pine)

$\begin{array}{ccc}\text { Seedlings } & 2 \text { to } 4 \text { in. } \\ \# & 4 \text { to } 6 \text { in. } \\ & 6 \text { to } 8 \text { in. }\end{array}$


Each 1

PLNUS MONGOLICA (Mongolian pine)

Seedlings

4 to 6 in. $\quad 3.00$

6 to 8 in. $\quad 5.00$

8 to $12 \mathrm{in.} \quad 7.00$

" $\quad 6$ to 8 in.

12 to 18 in 1.00

18 to 24 in. $\mathbf{1 . 5 0}$

24 ts 30 in. 2.00

PINUS MONTANA MUGHUS (Mugho pine)

2 to 4 in.

4 to 6 in.

$2.00 \quad 15.00$

$3.00 \quad 25.00$

6 to 8 in.

T:ansplants B\&B 10 to 12 in. 1.25

$4.00 \quad 30.00$

" 18 to 24 in. 3.00

PINUS MONTANA UNCINATA (Large Swiss pine)

$\begin{array}{llll}" & 4 \text { to } 6 \text { in. } & 2.00 & 15.00 \\ " & 6 \text { to } 8 \text { in. } & 2.50 & 20.00 \\ & 8 \text { to } 10 \mathrm{in} . & 3.00 & 25.00\end{array}$

8 to $10 \mathrm{in.} \quad 3.00 \quad 25.00$

10 to $15 \mathrm{in.} \quad 4.00 \quad 35.00$

PINUS NIGRA (Austrian pine)

$\begin{array}{crrrr}\text { Seedlings } & 2 \text { to } 4 \text { in. } & 2.00 & 10.00 \\ " & 4 \text { to } 6 \text { in. } & 2.50 & 15.00 \\ " & 6 \text { to } 10 \mathrm{in} . & 3.00 & 20.00 \\ & 10 \text { to } 15 \mathrm{in} . & 3.50 & 30.00\end{array}$

Transplants B\&B 12 to 18 in. 1.00

Trans B\&B 18 to $24 \mathrm{in.} 1.50$

2 to $3 \mathrm{ft} .2 .00$

Seedlings

2 to 4 in. 1.50

4 to 6 in. $\quad 2.00 \quad 10.00$

6 to 8 in. $\quad 2.50 \quad 15.00$

$\begin{array}{llll}\prime \prime & 6 \text { to } 8 \text { in. } & 2.50 & 15.00 \\ & 8 \text { to } 12 \text { in. } & 3.00 & 25.00\end{array}$

$"$ " 12 to 18 in.

5.00

PINUS RESINOSA (Red or Norway pine)

Seedlings

2 to 4 in.

4 to 6 in.

$" 6$ to $8 \mathrm{n}$.

Transplants B\&B 8 to 10 in

$4.00 \quad 35.00$

Transplants B\&B $\quad 4 \mathrm{ft}$. $\quad 3.00$

4.00

$\begin{array}{ll}3.00 & 25.00\end{array}$

$4.00 \quad 35.00$

Seedlings

$\begin{array}{cl}\text { Seedlings } & 2 \text { to } 4 \text { in. } \\ \text { " } & 4 \text { to } 6 \text { in. }\end{array}$

PINUS SYLVESTRIS (Scotch pine)

Seedlings

2 to 4 in.

4 to 6 in

6 to $10 \mathrm{in}$.

10 to 12 in.

12 to $18 \mathrm{in.}$

18 to 24 in.

seed from Riga forest 6 to $10 \mathrm{in}$.

" 10 to 12 in. Transplants B\&B 18 to 24 in $\quad .75$

$\begin{array}{llll}" & \quad 3 \text { to } 31 / 2 \mathrm{ft}_{1} & 2.00 \\ & \Rightarrow & 31 / 2 \text { to } 4 \mathrm{ft} . & 2.50\end{array}$

PINUS THUNBERGI (Japanese black pine)

Seedlings $\quad 4$ to 6 in. $\quad 3.00$ 6 to 8 in. $\quad 5.00$

$1.00 \quad 5.00$

$1.50 \quad 8.00$

$\begin{array}{ll}2.00 & 10.00\end{array}$

$3.50 \quad 25.00$

$\begin{array}{ll}4.00 & 30.00\end{array}$

5.00

$3.00 \quad 20.00$

$4.00 \quad 30.00$

PSEUDOTSUGA DOUGLASI (Douglas fir)

Transplants B\&B 12 to 18 in. 1.00 $" 18$ to 24 in. 1.50 " 24 to 30 in. 2.00 $\begin{array}{lll}\text { " } & 30 \text { to } 36 \text { in. } \quad 2.50 \\ 3 \text { to } 4 \mathrm{ft} . & \mathbf{3 . 5 0}\end{array}$ THUYA OCCIDENTALIS (American arbor vitae)

Seedlings

2 to 4 in. $\quad 2.00 \quad 15.00$ 4 to 6 in. $\quad 3.50 \quad 25.00$ 6 to 8 in. $\quad 4.00 \quad 35.00$ 2 to 4 in $\quad 3.00 \quad 20.00$

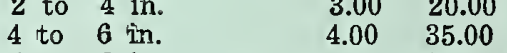

Transplants 6 to 8 in.

Transplants B\&B 12 to 18 in. $.60 \quad 50.00$

$6.00-50.00$

$\begin{array}{lrrrr}" \prime & 18 \text { to } 24 \text { in. } & .75 & 65.00 \\ " & 2 \text { to } 3 \text { ft. } & 1.25 & 100.00 \\ " & 3 \text { to } 4 \text { ft. } & 2.00 & 185.00\end{array}$

" $\quad 4$ ft. \& up. 3.00

THUYA OCCIDENTALIS COMPACTA ..Compact Ar. Vitae)

Transplants B\&B 6 to 10 in. .7565 .00

$" 10$ to 12 in. $1.00 \quad 90.00$

$" 12$ to 15 in 150

THUYA OCC. ELWANGERIANA (Tom Thumb A. V.)

Transplants B\&B 10 to 12 in. $.35 \quad 30.00$

" " 12 to 18 in $\quad .50 \quad 40.00$

$" \quad " \quad 18$ to 24 in. $\quad .75 \quad 65.00$

" 24 to 30 in. $1.00,90.00$

THUYA OCCIDENTALIS ERRICOIDES

Transplants B\&B 10 to 12 in. 1.00 $" 12$ to 18 in. 1.50 


\section{THUYA OCCIDENTAI IS GLOBOSA}

Transplants 4 to 6 in.

Transplants $B \& B \quad 6$ to 10 in

" $\quad 10$ to 12 in. $\quad .50 \quad 40.00$

" $\quad 12$ to 18 in. $\quad .75 \quad 65.00$

THUYA OCCIDENTALIS HOVEYI (Hoveys A. V.)

Transplants $\quad 4$ to 6 in. $\quad 15.00$

Transplants B\&B 10 to 12 in. $\quad .50 \quad 40.00$

" " $\quad 12$ to 18 in $.75 \quad 65.00$

THUYA OCCIDENTALIS LUTEA (Geo. Peabody A. V.)

Transplants 4 to 6 in. 20.00

Transplants B\&B 12 to 18 in. $1.00 \quad 75.00$

$\begin{array}{ccccc}" \text { "plants } & \text { " } & 18 \text { to } 24 \text { in. } & 1.50 & 125.00 \\ \text { " } & 2 \text { to } 3 \mathrm{ft} . & 2.00 & \end{array}$

THUYA OCCIDENTALIS PYRAMIDALIS (Pyramid A. V.)

Transplants $\quad 4$ to 6 in. $\quad 15.00$

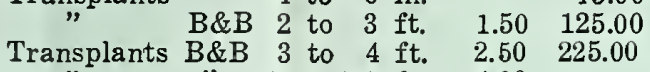

THUYA OCCIDENTALIS ALBA SPICATA (White tip A. V.)

Transplants B\&B 10 to 12 in. $.60 \quad 50.00$

" " 12 to $18 \mathrm{in}$. $\quad .75 \quad 65.00$

$\begin{array}{llll}\prime \prime \quad 18 \text { to } 24 \text { in. } 1.50 & 125.00\end{array}$

$" \quad " \quad 2$ to $3 \mathrm{ft}$. 2.00

" 3 to $4 \mathrm{ft}$. 3.00

THUA OCCIDENTALIS WARREANA (Siberian A. V.)

Transplants B\&B 6 to 10 in. $.50 \quad 40.00$

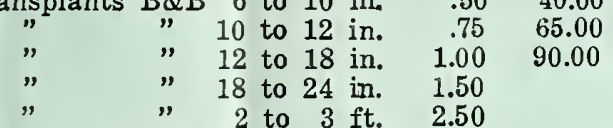

THUYA OCCIDENTALIS WOODWARDI (Woodward globe)

Transplants B\&B 6 to 10 in. 80

$" \quad " \quad 10$ to 12 in. 1.25

12 to 15 in 1.75

THUYA ORIENTALIS (BIOTA) (Chinese A. V.)

Although the seed of the different varieties of Chinese Arbor Vitae is selected with care from trees having the definite characteristics of the variety, on account of the possibility of variation in form, color, etc., we cannot guarantee any definite percentage of them to develop the exact form for which they are named. The Thuya orientalis Aurea is not Berchman's Golden. The seed is supposed to have been collected from trees showing distinct golden foliage. At their present age they show little difference from plain Chinese. The Nana is a new variety for us. We purchased the seed from a reliable dealer, which is supposed to have come from dwarf trees, we do not know what percentage of them come true.

$\begin{array}{llll}\text { Seedlings } & 2 \text { to } 4 \mathrm{in} . & 1.50 & 10.00 \\ & 4 \text { to } 10 \mathrm{in} . & 2.00 & 15.00\end{array}$

Transplants B\&B 2 to $3 \mathrm{ft} .2 .00$

THUYA ORIENTALIS (BIOTA) AUREA (Chinese Golden) Seedlings 2 to $\&$ in. $\quad 2.50 \quad 15.00$ " 4 to $10 \mathrm{in}$. $3.50 \quad 25.00$ THUYA ORIENTALIS AUREA NANA (Berckmans golden) Transplants B\&B 10 to 12 in. $1.00 \quad 75.00$ " $\quad " \quad 12$ to 15 in. $1.50 \quad 125.00$ $\begin{array}{lllll}\prime \prime & \quad 15 \text { to } 18 \text { in. } & 2.00 & 150.00 \\ , \quad & 18 \text { to } 24 \text { in. } & 2.50 & 200.00\end{array}$

THUYA ORIENTALIS (BIOTA) COMPACTA (Com. A. V.)
Seedlings
2 to 4 in.
$2.50 \quad 15.00$
Seedlings
4 to 6 in.
$3.50 \quad 25.00$

THUYA ORIENTALIS (BIOTA) NANA (Chinese dwarf)

$\begin{array}{llll}\text { Seedlings } & 2 \text { to } 4 \text { in. } & 3.50 & 25.00 \\ & 4 \text { to } 6 \text { in. } & 4.00 & 35.00\end{array}$

THUYA ORIENTALIS (BIOTA) PYRAMID (Ch. pyramid)

Seedlings 2 to 4 in. 2000

Transplants B\&B 12 to 18 in.

\&B 12 to 18 in. $\quad 1.00 \quad 90.00$

" $\quad 2$ to $3 \mathrm{ft}$. 2.00

3 to 4 ft. 3.00

" 4 to $5 \mathrm{ft}$. 4.00

\section{SHRUBBERY}

ALTHEA ROSEA (Rose of sharon)

Each $\quad 100 \quad 1000$

Seedlings

6 to $12 \mathrm{in.}$

12 to 18 in.

18 to $24 \mathrm{in.}$

$2.00 \quad 8.00$

$2.50-15.00$

4.00

AZALEA MOLLIS

Bed Trans. 2 yr. 6 to 12 in. $\quad .45 \quad 40.00$ 
HYDRANGEA PANICULATA GRANDIFLOKA (Hy. P. G.)

Our Hydrangea P. G. are all strong growing strain, no dwarfs. They have been fertilized, and are stocky, well-rooted plants. Let

\begin{tabular}{|c|c|c|c|c|c|c|c|}
\hline & & & & 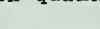 & Each & 100 & 1000 \\
\hline Layers & & 4 & to & $6 \mathrm{in.}$ & & 2.50 & 10. \\
\hline & & 6 & to & 15 in. & & 3.50 & 25. \\
\hline$"$ & & & to & $2 \mathrm{ft}$. & & 4.50 & 35.0 \\
\hline$"$ & & 2 & to & $3 \mathrm{ft}$. & & 6.00 & $50 d$ \\
\hline Rooted & Cuttings & 3 & to & 6 in. & & 2.50 & 0. \\
\hline & & 6 & to & 12 in. & & 4.00 & \\
\hline$"$ & $"$ & 12 & to 1 & 18 in. & & 6.00 & 45.00 \\
\hline$"$ & ", & 18 & to & 24 in. & .10 & 8.00 & 65. \\
\hline Transpl & lants & 6 & to & 12 in. & .10 & 7.00 & \\
\hline " & & 12 & to & $18 \mathrm{in.}$ & .15 & 10.00 & \\
\hline$"$ & & 18 & to & 24 in. & .20 & 15.00 & \\
\hline
\end{tabular}

\section{LABURNUM VULGARE}

Seedlings, 2 yr. 3 to 6 in. $\quad 4.00 \quad 35.00$ LIGUSTRUM AMURENSE (Amoor North privet)
$2 \mathrm{yr}$,
12 to 18 in.
$5.00 \quad 40.00$

$6.00 \quad 50.00$

LIGUSTRUM OBTUSIFOLIUM (Ibota privet)

Transplants 2 to $3 \mathrm{ft}$. $\quad .15 \quad 10.00$

LIGISTRUM OVALIFOLIUM (California privet)

Rooted Cuttings 6 to 12 in. $\quad 2.00 \quad 10.00$

12 to $18 \mathrm{in.} \quad 2.50 \quad 15.00$

LIGISTRUM REGELIANUM (Regels privet)

Rooted Cuttings 3 to 6 in. $\quad 3.50 \quad 30.00$

6 to $12 \mathrm{in.} \quad 4.50 \quad 40.00$

LONICERA MORROWI (Morrows honeysuckle)

$\begin{array}{crrrr}\text { Rooted Cuttings } & 3 \text { to } 6 \text { in. } & 2.50 & 20.00 \\ " \# & 6 \text { to } 12 \text { in. } & 3.00 & 25.00 \\ " & 12 \text { to } 18 \text { in. } & 4.00 & 35.00\end{array}$

Transplants $\quad 4$ to $5 \mathrm{ft}$. $\quad .25 \quad 20.00$

PHILADELPHUS CORONARIUS

$\begin{array}{ccc}\text { Rooted Cuttings } 6 \text { to } 12 \text { in. } & 4.00 \\ " \# & 12 \text { to } 18 \text { in. } & 5.00 \\ " & 18 \text { to } 24 \text { in. } & 6.50\end{array}$

Transplants $\quad 4$ to $5 \mathrm{ft}$. .25

PHILADELPHUS MONT BLANC (Mock orange)

Rooted Cuttings 6 to 12 in. $\quad 3.00$

Transplants $\quad 4$ to $5 \mathrm{ft}$. $.25 \quad 20.00$

SAMBUCUS AUREA (Golden elder)

Rooted Cuttings 3 to 6 in. $\quad 4.00$

SPIREA BILLARDI ROSEA

Rooted Cuttings 6 to 12 in. $\quad 1.50 \quad 10.00$

12 to 18 in.

$" \quad " \quad 18$ to $24 \mathrm{in.} \quad 3.00 \quad 20.0 \mathrm{c}$

$" \quad \Rightarrow \quad 2$ to $3 \mathrm{ft} \quad 4.00 \quad 30.00$

Transplants $\quad 18$ to 24 in. $.15 \quad 10.00 \quad 90.00$

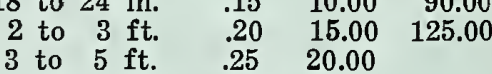

SPIREA CALOSA ALBA (Japonica)

Rooted cuttings 3 to 6 in

Transplants heavy 18 to 24 in 25

4.00

SPIREA DOUGLASI

Rooted Cuttings 6 to 12 in. $\quad 2.50 \quad 15.00$

" " 12 to 18 in $\quad 3.00 \quad 20.00$

$\begin{array}{llll}18 & \text { to } 24 \mathrm{in.} \quad .06 \quad 4.00 \quad 30.08\end{array}$

SPIREA OPULIFOLIA (Nincbark)

$\begin{array}{llllll}\text { Transplants } & 3 \text { to } & 4 \mathrm{ft} & .15 & 10.00 & 90.00\end{array}$

4 to 5 ft. $\quad .20 \quad 15.00 \quad 125.00$

SPIREA OPULIFOLIA AUREA (Golden Spirea)

$\begin{array}{llllll}\text { Transplants } & 3 \text { to } 4 \mathrm{ft} \text {. } & .25 & 20.00 & 175.00\end{array}$

SPIREA PRUNIFOLIA

Rooted Cuttings 3 to 6 in. $\quad 3.50$

" $\quad 12$ to $18 \mathrm{in.} \quad 5.00$

SPIREA REEVESIANA

Rooted Cuttings 3 to 6 in. $\quad 3.00 \quad 20.00$

SPIREA RICHMENSIS

Rooted Cuttings 3 to 6 in. 2.00

" 6 to 12 in $\quad 3.00$

$" \quad 12$ to $18 \mathrm{in.} \quad 4.00$

SPIREA TOMENTOSA

Rooted Cuttings 3 to $f$ in. $\quad 3.00$

" " 12 to 18 in. $\quad .05 \quad 4.00$

" $\quad 18$ to 24 in. $\quad .06 \quad 5.00$

SPIREA VAN HOUTEI

Rooted Cuttings 6 to 12 in. $\quad 3.50 \quad 30.00$

Transplants $\quad 12$ to $18 \mathrm{in}$. $\quad 15 \quad 4.50 \quad 40.00$

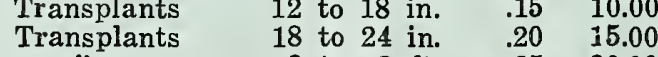

2520.00

STEPHANANDRA FI

$\begin{array}{ccccc}\text { STEPHANANDRA FLEXOSA } & & \\ \text { Rooted Cuttings } & 3 \text { to } 6 & \text { in. } & & 4.00 \\ \text { Transplants } & 2 \text { to } & 3 \mathrm{ft} . & .35 & \end{array}$

$\begin{array}{ccc}\text { Transplants } & 2 \text { to } 3 \mathrm{ft} . & .35 \\ \text { SYMPHORICARPUS VULGARIS (Coralberry) }\end{array}$

Transplants 12 to 18 in. $15 \quad 10.00$

$\begin{array}{llll}\prime \prime & 18 \text { to } 24 \text { in. } \quad .20 & 15.00\end{array}$

2 to 3 ft. $\quad .25 \quad 20.00$ 
VIBURNUM OPULUS (High bush cranberry)

Lining out 3 to 6 in.

" " 6 to $12 \mathrm{in.}$ 12 to $18 \mathrm{in.} \quad 10 \quad 8.50$

Transplants 12 to 18 in. $\quad .25 \quad 20.00$ 18 to 24 in. $\quad .30 \quad 25.00$

" $\quad 2$ to $3 \mathrm{ft} . \quad .35 \quad 30.00$

VIBURNUM OPULUS STERLIS (Common snowball)

\begin{tabular}{|c|c|c|c|c|c|}
\hline \multirow{2}{*}{\multicolumn{6}{|c|}{ Levers }} \\
\hline & 3 to & 6 in. & & 5.00 & 40.00 \\
\hline " & 18 to & 24 in. & .12 & 10.00 & 90.00 \\
\hline$"$ & 2 to & $3 \mathrm{ft}$. & .15 & 12.00 & \\
\hline Rooted Cuttings & 1 to & 3 in. & & 4.00 & 30. \\
\hline " " " & 3 to & $6 \mathrm{in.}$ & & 6.00 & \\
\hline Transplants & 18 to & 24 in. & .25 & 15.00 & \\
\hline & 2 to & $3 \mathrm{ft}$. & .30 & 20.00 & \\
\hline$"$ & 3 to & $4 \mathrm{ft}$. & .40 & 25.00 & \\
\hline$"$ & 4 to & $5 \mathrm{ft}$. & .50 & 35.00 & \\
\hline \multicolumn{6}{|c|}{ VIBURNUM PLICATUM (Japan Snowball) } \\
\hline Layers & 3 to & 6 in. & & 5.00 & 45. \\
\hline$"$ & 6 to & 12 in. & & 7.00 & 60 \\
\hline$"$ & 12 to & $18 \mathrm{in.}$ & & 8.50 & 75.0 \\
\hline$"$ & 18 to & 24 in. & & 11.00 & 100. \\
\hline \multicolumn{6}{|c|}{ WEIGELIA ROSEA (Pink Weigelia) } \\
\hline Rooted Cuttings & 3 to & 6 in. & & 4.00 & \\
\hline$"$ & $\begin{array}{r}6 \text { to } \\
12 \text { to }\end{array}$ & $\begin{array}{l}12 \text { in. } \\
18 \text { in. }\end{array}$ & .08 & $\begin{array}{l}5.00 \\
7.00\end{array}$ & \\
\hline \multicolumn{6}{|c|}{ WEIGELIA VARIEGATA } \\
\hline Rooted Cuttings & 1 to & 3 in. & .03 & & \\
\hline$"$ & $\begin{array}{l}3 \text { to } \\
6 \text { to }\end{array}$ & $\begin{array}{r}6 \text { in. } \\
12 \text { in. }\end{array}$ & $\begin{array}{l}.05 \\
.06\end{array}$ & $\begin{array}{l}4.00 \\
5.00\end{array}$ & \\
\hline
\end{tabular}

TREE SEEDLINGS-Nursery Grown ACER CAMPESTRIS (English Maple)

4 to 6 in.

6 to 12 in.

12 to 18 in.

18 to 24 in.

ACER GINNALA

3 to 6 in. $\quad 3.00 \quad 25.00$

6 to 12 in. $\quad 4.00 \quad 30.00$

ACER S.ACCHARINUM (DASYCARPUM) (Silver maple)

6 to 12 in. $\quad 1.00 \quad 5.00$

1 to $2 \mathrm{ft}$. $\quad 2.00 \quad 10.00$

ACER SACCHARUM (Sugar maple)

6 to 12 in. $\quad 1.50 \quad 8.00$

12 to 18 in. $\quad 2.00 \quad 10.00$

18 to 24 in. $\quad 2.50 \quad 15.00$

2 to $3 \mathrm{ft}$. $\quad 3.00 \quad 20.00$

3 to $4 \mathrm{ft}$. $\quad 5.00 \quad 35.00$

AESCULUS GLABRA (Ohio buckeye)

3 to 6 in. $\quad 3.50 \quad 20.00$

6 to 12 in. $\quad 4.00 \quad 30.00$

BETULA ALBA (White birch)

6 to 12 in. $\quad 5.00 \quad 40.00$

12 to $18 \mathrm{in}$. $\quad 6.00 \quad 50.00$

18 to $24 \mathrm{in}$. $\quad 7.50 \quad 65.00$

2 to $3 \mathrm{ft} . \quad 8.50 \quad 75.00$

CERCIS CANADENSIS (Judas tree)

2 to 3 in. $\quad 1.00 \quad 6.00$

3 to 6 in. $\quad 1.50 \quad 10.00$

6 to 12 in. $\quad 2.50 \quad 20.00$

12 to $18 \mathrm{in.} \quad 4.00 \quad 30.00$

FRAXINUS AMIERICANA

3 to 6 in. $\quad 2.00$

6 to 12 in. 2.50

JUGLANS CINEREA, (Butternut)

6 to 12 in. $\quad 2.00 \quad 12.00$

JUGLANS NIGRA (Black Walnut)

6 to 12 in. $2.00 \quad 15.00$

LIRIODENDRON TULIPFERA (Tulip tree)

6 to 12 in. $1.50 \quad 10.00$

1 to $2 \mathrm{ft}$. $\quad 2.50 \quad 20.00$

$\begin{array}{ccc}\text { MAGNOLIA ACUMINATA (Cucumber Tree) } \\ 2 \text { to } 3 \text { in. } & 4.50 \quad 40.00 \\ 3 \text { to } 6 \text {. } & 8.00 & 70.00\end{array}$

3 to 6 in. $\quad 8.00 \quad 70.00$

6 to 9 in. $\quad 10.00 \quad 90.00$

9 to $12 \mathrm{in.} \quad 12.00$

NYSSA SYLVATICA (Sour Gum)

$\begin{array}{llll}\text { seedlings } & 3 \text { to } 6 \text { in. } & 2.00 & 10.00\end{array}$

PLATANUS ORIENTALiS (Eup. plane tree)

From Cuttings 3 to 6 in. $\quad 3.00$ 


$$
18 \text { to } 24 \text { in. }
$$

POPULUS SIMONSI (Chinese poplar)

$$
\begin{array}{ccccc}
\text { From Cuttings } & 6 \text { to } 12 \mathrm{in} . & 1.50 & 10.00 \\
\text { " } & 12 \text { to } 18 \mathrm{in} . & 2.00 & 15.00
\end{array}
$$

" " " 12 to $18 \mathrm{in.} \quad 2.00 \quad 15.00$
PRUNUS (Cerasus) SEROTINA (Black Cherry) Seedlings 3 to 6 in. $\quad .75 \quad 5.00$ " 6 to 12 in. $\quad 1.00 \quad 7.00$ QUERCUS ALBA (White oak)

$$
\begin{array}{rrr}
3 \text { to } 6 \text { in. } & 2.00 & 15.00 \\
6 \text { to } 12 \text { in. } & 3.00 & 20.00
\end{array}
$$

$\begin{array}{cccc}\text { SALIX BABYLONICA } \& \text { SALIX ELEGANTISSIMA } & \\ \text { From Cuttings } & 6 \text { to } 12 \mathrm{in.} & 1.50 & 10.00\end{array}$

$\begin{array}{crrrr}\text { From Cuttings } & 6 \text { to } 12 \mathrm{in.} & 1.50 & 10.00 \\ " & " & 12 \text { to } 18 \mathrm{in} . & 2.00 & 15.00 \\ " & \quad " & 18 \text { to } 24 \mathrm{in} . & 2.50 & 20.00 \\ " & 2 \text { to } 3 \mathrm{ft} . & 3.00 & 25.00\end{array}$

TILIA AMERICANA (American Linden) 4 to 6 in. $\quad 3.00 \quad 25.00$ 6 to 9 in. $\quad 5.00 \quad 40.00$

ULMUS AMERICANA (Am. white elm) $\begin{array}{rrr}3 \text { to } 6 \text { in. } & .50 & 2.50 \\ 6 \text { to } 12 \text { in. } & 1.00 & 5.00\end{array}$

ULMUS PUMILLA Seedlings

MISCELLANEOUS

AMELOPSIS QUINQUEFOLIA

2 year
ASPARAGUS, CONOVER'S COLOSSAL

1 year

$\begin{array}{lll}2 \text { year } & 1.00 \quad 7.00\end{array}$

ASPARAGUS (Washington rustproof)

1 year

10.00

CURRANTS (London Market, red cross \& wilder) No. 1 Plants $\quad .10 \quad 7.50$

BLACK RASPBERRY (Plum farmer \& Kansas)

Tips

2.00

URPLE RASPBERRY (Shaffer) Tips

ED RASPBERRY (Suckers)

Marlboro

(New) Cayuga $\quad 3.00$

YUCCA FILAMENTOSA

From root cuttings

$1 \mathrm{yr}$.

$2.00 \quad 15.00$

RUNUS NEWPORT (Red leaf plum)

$\begin{array}{llll}1 \text { year whips } & 2 \text { to } 3 \mathrm{ft} . & .40 & 30.00\end{array}$

MALUS-Flowering Crabs $\quad .50 \quad 40.00$

Atropurpurea, Atrosanguinea, Ioensis

Niedwetzkana, Sargenti, Whips 1 to $2 \mathrm{ft}$.

Perennials $2 \mathrm{yr}$. field grown,10c each except where noted

Achillea, Boule de neige

Aster, Climax, $15 c$ each

Boltonia Latisquama

Desmodium, bicolor, 35c each

Dianthus plumarius, $15 \mathrm{c}$ each

Helianthus mollis

HIBISCUS (Giant Mallows)

Seedlings

Tramsplants, Red

1 year

$\begin{array}{lll} & 1.50 & 10.00 \\ 10 & 7.00 & 60.00\end{array}$

Transplants, Pink or White $\quad .08 \quad 5.00 \quad 40.00$

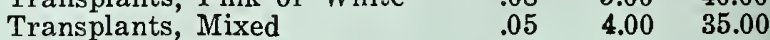

Iberis sempervirens

Phlox sublata rosea

Rudebeckia purpurea, $15 \mathrm{c}$ each

Rudebeckia Golden Glow, 7c each

Shasta Daisy, Etoile D'or

Veronica erica

Veronica rupestris

Veronica spicata

Vernnica spicata alba

Veronica Longifolia, 15c each

DAHLIAS, 10c each

A. D. Livonia (Show Type) Soft Pink

Bonnie Blue (Decorative)

Easton (Decorative) Turkey Red

GLADIOLUS, 5c each

Joe Coleman-Red, Golden, Princess, Yellow. 